\title{
The Victory of Partai Amanat Nasional (PAN) in Ngada as the Form of Public Distrust against the Party
}

\author{
Bertolomeus Loji Sua•
}

\begin{abstract}
A political party is a political organization represented by individuals who work for the people with the ideology embraced by the party itself. The task of a political party is to provide political education and lead according to the people's desires. But what if today's political party has unconsciously formed the public distrust? The phenomenon of the PAN victory in Ngada district-Nusa Tenggara Timur (NTT) was a symbol of Ngada's public distrust toward the party itself, as well as the previous political parties that had won in Ngada. This study aimed to assess the public distrust toward political parties, by looking at the phenomenon of the PAN victory in Ngada. The method used in this research was qualitative research, with in-depth interviews with sources in the field. In this study, the author found some interesting things related to the society and politics in Ngada. One of those things was that the people neither trust nor put hope in the political parties in the matter of responding to their wishes and communities' development in Ngada. The PAN victory in Ngada was an interesting phenomenon in the political sphere that showed the public's distrust of the parties today.
\end{abstract}

\section{Keywords:}

victory; parties; public distrust.

\section{Introduction}

In the colonial era, parties were formed to look for and formulate a national identity on one side, and to strengthen the struggle for independence on the other. Therefore, it is not surprising that great ideologies such as Islamism, nationalism, and Marxism underlie the formation of the party in the period of national resurgence (Haris, 2014: p. 21). In its development after the independence, the formation and presence of the party has aimed more towards being a political medium to accommodate the needs of the people and solve the variety of existing political problems.
Although political parties initially represented the desires of different social or ideological groups, the colonial-era parties contributed to the search for the "discovery" of Indonesian identity that underlies the formation of the Republic (Haris, 2014, p. 47). The presence of a party clearly has significance, even if very basic in its struggle. Moreover, the adopted ideology and the purpose of the struggle can be clearly seen and felt in the movement.

After the independence of Indonesia in 1945, Indonesia held its first general election in 1955, followed by four parties, namely Partai Nasional Indonesia (PNI), Partai Masyumi, Partai

\footnotetext{
- Department of Communication Studies, Faculty of Social Science and Political Science, The University of Sebelas Maret.

Email: imdibertho@gmail.com.
} 
Nahdatul Ulama (NU), Partai Komunis Indonesia (PKI) and Partai Syarikat Islam Indonesia (PSSI). One of the important functions and roles of political parties is political education or intensive and effective political socialization; besides educating and making people aware of their rights and obligations, political parties also build their own image (Arifin, 2011, p. 181). If it was examined further, political education began to be run by the government in the era of the Indonesian revolution (1945-1950), followed by Liberal Democracy (1950-1959), Old Order (1959-1966), New Order (19661998), and finally Reform Order (1998-present) (Arianto, 2016, p. 64). However, the functions of political parties cannot be implemented properly; this can be seen from the efforts of the elites who prioritize the pursuit of power in government rather than improving the quality of the political education of society (Asrinaldi, 2014, p. 156). The phenomenal thing was the New Order regime: thirty-two years of political authoritarianism. Regardless of the authoritarian ways of the Soeharto regime, the role of Golkar as a state party was clearly visible, as the reciprocal political alignments between parties and mass supporters were clear and measurable. As a whole, it can be spoken of as a degree of partisanship, which is when the emergence of the feeling of closeness to or identification with a particular party can be ascertained.

After the collapse of the New Order regime, parties then emerged with various colors and ideologies; one of the parties was $P A N$. This Islamic party then followed the election in 1999 and was considered as a quite calculated party. In the regional sphere, PAN in Ngada is a party which does not have the popularity of Golkar and PDIP, which are the mainstay parties and have the people's trust in Ngada. At the National level, the electability of PAN is not higher than Golkar and PDIP. Since PAN's participation in the 1999 election to present, the electability of $P A N$ may be said to be "mediocre." In the acquisition of seats in the 2009 legislative elections, PAN ranked fifth, with $8,206,955$ votes or $7.88 \%$ of the national vote, below the Partai Keadilan Sejahtera (PKS). The influence of $P A N$ and its members had not been able to compete with other major parties, including Partai Demokrat, which was new to the 2009 legislative elections.

In Ngada's 2014 legislative elections, PAN was able to get seven seats in Parliament. The PAN victory in Ngada became an interesting phenomenon to be studied as, in Ngada, the level of public confidence in the party is very low. Emerging from this phenomenon was the important issue of analysing the victory and its relationship with the public distrust of the party. What factors affected PAN's victory in Ngada? How could PAN's victory in Ngada be a form of the public's distrust of the party?

Both questions above are important as analysis material of PAN's victory in Ngada as a form of mistrust of the party. This is because their victoryis based on a limited public understanding about the role of political parties in general, especially PAN. However, PAN won seven seats in DPRD Ngada by defeating major parties such as PDIP and Golkar.

\section{Methods}

In conducting research at Ngada, the authors used qualitative research methods, with in-depth interviews with sources in the field; these sources included community members, political figures, community leaders, successful teams and local journalists.

In obtaining data in the field, the researcher selects informants from various circles or community groups, with the goal of authenticating the research data. Researchers come into direct contact with relevant political actors, using in-depth interview techniques. Data collection techniques are the most strategic step in research, because the main purpose of the research is to get data (Sugiyono, 2013, p. 62). 
Interview techniques as a method of data collection conducted by researchers during research in the Ngada district related to the party winning apparently effortlessly in the 2015 election.

Esterberg (2002) in (Sugiyono, 2013, p. 72) defines interview as follows: "A meeting of two persons to exchange information and ideas through question and response, resulting in communication and joint construction of meaning about a particular topic." The interview is a meeting of two people to exchange information and ideas through question and answer so that it can create meaning for a particular topic.

Esterberg (2002), in Sugiyono, (2013, p. 73-74) presents several interview types, namely structured, semi-structured, and unstructured interviews. Structured interviews are used as data collection techniques by authors where the researchers have known exactly what information is to be obtained from the interviewee. In structured interviews, researchers must first determine the people to be interviewed who can best provide information to support the research data. Researchers determine informants from various backgrounds, such as the general public, public officials, politicians, non-governmental organizations (NGOs), and local journalists.

\section{Result}

\section{The Democracy and the Election in Ngada}

One of the characteristics of a country that embraces democracy is the right of the people to be freely involved in elections and to determine their own political choices. In the beginning, democracy became a direct description of society's opposition to the authoritarian system in government by applying a mass meeting system (Yumitro, 2013, p. 36). The application of democracy in Indonesia since its independence has been known by different Democratic terms, following the fluctuation of internal political dialectics. The political communication within a country that embraces a democratic political system has a greater emphasis on the role of the media in any political activity. Moreover, the communication experts claim that mass media is a fourth estate, after the executive, legislative and judiciary, in the thought of Trias Politics ${ }^{2}$ (Holik, 2005, p. 58).

In a democratic country, political conflict is also unavoidable. The political conflict between the political elites or the contradiction of people's partisanship towards an ideology or particular political stream is part of life. The dynamic of fluctuating communication is a natural thing, because it is part of the formation cycle of established democratic behavior (Yuliyanto, 2014 , p. 49). It has become a consequence that, in the practice of politics, the collisions and contradictions of understanding an ideology are common, but it is clearly a bridge that refers to the achievement of political objectives.

The roles and duties of political parties are not only as the channels of the people's needs and aspirations, but also as the institutions that provide political education to the public. The direct election of regional heads takes an important role as a form of political education on Indonesian democracy. The idealism of the direct election of regional heads is a fundamental implication in the effort to revise Law No. 22 of 1999 on Regional Regulation and Law no. 23 of 1999 Concerning Financial Balance Between Central and Local Government In Early Year 2001 (Wahidin, 2008, p. 134).

\footnotetext{
This is also confirmed by Thomas Calyle (1907) i.e. "The press is a power, a branch of a goverment with an inalienable weight in law-making, derived from the will of the people." However, in the case of the regional heads election in some regions in Indonesia, especially based on the research conducted in Ngada, media is not the dominantelement in the activities of political communication. A political actor (candidates of leader), organizations and people are the main pillars in the activities of political communication, in the spread of ideas (messages), political propaganda and political imaging.
} 
The Ngada regency is one of the districts in the province of East Nusa Tenggara (NTT), located on the central island of Flores, with its capital being Bajawa. From a political perspective as a voter, most of the people in Ngada are traditional voters influenced by sociocultural issues, values and origin, and a small proportion of the rational electorate.

The election of regional heads was held simultaneously on December 9, 2015, in 9 provinces, 224 districts, and 36 cities. The next elections were held on February 2017 in 7 provinces, 76 districts, and 18 cities. In June 2018 , the election of regional heads will be held in 17 provinces, 115 districts, and 39 cities (http://m.sergapntt.com/). The Ngada regency is one of the districts in Indonesia following the election on December 9. With the political support of each party, three Regent candidates and a Vice Regent of Ngada successfully advanced in the election on December 9, 2015, among others; Kornelis Soi, $\mathrm{SH}$ and Joseph Bei (KONSEP), Paulinus No Watu, S. Sos and Bernadus Dhey Ngebu, SP (PADI), and Marianus Sae, S.A.P and Dr. Paul Soliwoa (MULUS). The Mulus pair were incumbent candidates who nominated themselves to relead Ngada in 2016-2020.

The Mulus pair is supported by Partai Amanat Nasional (PAN), Partai Golkar (GOLKAR) and Partai Hati Nurani Rakyat (HANURA); the Konsep package is supported by Partai Demokrasi Indonesia Perjuangan (PDIP) and Partai Nasional Demokrat (NASDEM); and the Padi package is supported by Partai Gerindra and Partai Kebangkitan Bangsa (PKB). In the first round of the regional heads election of Ngada on December 9, 2015, based on a Real Count by KPU (General Election Commission) of Ngada, Marianus Sae and Paulus Soliwoa won the hearts of the Ngada people with 52,164 votes, or $68.05 \%$, followed by Kornelis Soi and Joseph Bei with 12,667 votes (16.52\%) and Paulinus No Watu and Bernadius Dhey Ngebu (with 11,829 votes $(15.43 \%)$. With the number of votes, the
Mulus pair successfully won the 2015 election and was entitled to lead Ngada in the period 2016-2020, or Mulus vol. II.

The contradictions in political democracy at the international and national levels are interesting to examine, but the political allegations at the regional level are equally important from a concern and research aspect. In the presidential election in Indonesia, political communication tends to focus on the mass media as political propaganda to create the image of the candidates, and the people can choose freely as a reflection of democracy. In today's digital era, the mass media becomes a funnel for political objectives, but this is not the case in Ngada. The political phenomenon in Ngada directly breaks the assumptions of mass media and the political relationships that are so inherent in the present.

The political phenomenon of the regional heads election in Ngada is an interesting one, especially when Marianus Sae and Paul Soliwoa, who made up the MULUS pair, were selected by the people in the second period for the tenure of 2016-2020. Meanwhile, in the first tenure period of 2011-2015, some people, officials and community organizations judged that many contradictions arose, especially regarding policy making and political decisionmaking. However, the negative assumptions regarding Marianus Sae are not supported by the track record of his political policy and the development that arose in Ngada. On the other political side, the interesting thing is the extent of public support for PAN as a political party supporting Marianus Sae.

The electability of PAN in Ngada increased when Marianus Sae entered as part of the party and nominated himself as the Regent of Ngada in 2011. Partai Demokrasi Indonesia Perjuangan (PDI) and Partai Golkar, as the parties with the highest electability in Ngada, were under $P A N$. At the legislative elections in Ngada for the period 2014-2019, PAN won seven seats in Ngada's Regional House of 
Representatives. PAN became the political party that got the most seats in the Regional House of Representative in Ngada, followed by Partai Nasdem with four seats; PDIP, PKB, Golkar and Hanura received three seats each. Meanwhile, Partai Gerindra got two seats (http://www.tribunnews.com). In addition, at the provincial level of East Nusa Tenggara (NTT), PAN only got four seats, behind Partai Hanura and Partai Kebangkitan Bangsa (PKB), which got five seats. Partai Golongan Karya (Golkar) was determined to control the Regional House of Representatives of NTT by holding the chairman position. Partai Golkar passed 11 legislative candidates to become members of the Regional House of Representatives of NTT in the period of 2014-2019; meanwhile, the vice chairman's seat belongs to the Partai Demokrasi Indonesia Perjuangan (PDIP) and Partai Gerindra. Looking at the comparison of PAN's electability in NTT and Ngada, it could be said that the increase in PAN's electability in Ngada with the acquisition of seven seats in the Regional House of Representatives of Ngada was influenced by the image of Marianus Sae in the public's eyes. The approach to the lower community and the development of village infrastructure became the main focus for Marianus Sae. This approach was indirectly a form of political branding to the people, a way of effective political communication. If politicians understand voters, they can more effectively communicate by knowing who the voters are, what they want and how to touch them by expanding the more targeted and desired communications of voters (Marshment, 2009, p. 170).

This political phenomenon becomes an interesting one to be studied with the perspective of political communication. In facing the regional heads election of 2016, positive and negative images were created by the public about the figure of Marianus Sae. Nevertheless, he was re-elected in the 2016 election as the Regent of Ngada who continued his own baton relay. Looking at the political phenomenon associated with the victory of PAN in Ngada, both at the level of legislative candidate election (Caleg) and the victory of the Ngada election, conclusions could be drawn from different viewpoints, namely the public's distrust of the party in Ngada district.

In the history of the general election in Ngada, even at the provincial level of East Nusa Tenggara (NTT), PAN has never recorded a big victory as happened in 2014. This was also confirmed based on the interviews of the authors with the reporters of Flores Post in Ngada, as well as the legislative members and the Chairman of the Regional House of Representatives (DPRD) in Ngada.

As a political party, PAN certainly has a line or the basics of the identity of the party. PAN itself is a party which has Pancasila ideology, but it is based on religion (Islam). However, almost $90 \%$ of Ngada people are Catholic. This was where two understandings met with the same political objective, namely the effort to increase the electability of PAN in Ngada. Why this happened in Ngada and how the Ngada people see politics today is a line of questioning that must be explored in their uniqueness.

\section{The Effect of Political Communication}

The superiority of PAN in the legislative elections (pileg) won seven seats in the Regional House of Representatives of Ngada, and the support for candidates from PAN in district elections was very high. This political phenomenon became interesting to be studied more deeply because the big parties such as PDIP and Golkar, which often become the mainstay of the Ngada people, seemed abandoned. The people were more interested in focusing their attention and choices on PAN. This phenomenon can be explained by a sharp analysis of political communication theory. The term political science (science politique) was first used by Jean Bodin in Europe in 1576, then Thomas Fitzherbert and Jeremy Bentham 
in 1606. The recent political definitions put more emphasis on the state in relation to the dynamics of people, as referenced by Kaspar Bluntscli, who stated that "politics is the science which is concerned with the state, which endeavors to understand and comprehend the state in its conditions, in its essential nature, its various forms of manifestation, its development." Even Harold D. Laswell more firmly formulates politics as a science of power: "When we speak of the science of politics, we mean the science of power" (Cangara, 2016, p. 23). In addition, Harold D. Laswell explains that an easy way to describe an act of communication is by answering the questions; Who? What was done? Which channel was used? To whom? Which effect was caused? (Nimmo, 2011, p. 13).

In its activities, political communication is not only within the internal scope, but also the external (Syah Putra, 2015, p. 69). Political participation is the activity of citizens, acting as individuals, which is intended to influence the decision-making of the government. The expected effect of political communication is the creation of an understanding towards the system of government and political parties, where the nuances will lead to voting in elections (Cangara, 2016, p. 32).

At a practical level, political communications actors such as politicians take advantages of all the elements that exist in operating their functional politics (La Nora, 2014, p. 48). As a political actor, Marianus Sae in his candidacy as the Regent of Ngada utilized elements of existing political communication, with the exception of channels and electronic media. This is related to the limitations of existing facilities and infrastructure in Ngada. In this case, political parties as the channeling institutions of the people's desires need political communication skills that contain grounded messages related to the transformation of ideas, attitudes and political behavior in addressing the issues and the dynamics of political development (La Nora, 2014, p. 48). The utilization of all elements in political communication affect the electability of a party or the political actors in it. For the regional heads election of Ngada, in both the role of PAN and organizational bodies in election activities, Marianus Sae as a political actor is also very influential. This is because of the image of Marianus Sae held by the public of Ngada for the actions and policies that are running and will be continued as the incumbent candidate from PAN.

Therefore, in this section, it is necessary to see the continuity between political actors and political communication, because both must run in balance. Marianus Sae as the political actor has an important role in delivering political messages to the people of Ngada. The importance of political communicators becomes significant when the political communications actors are involved in political spaces that require ima public image. By transforming the ideas through political messages, political communicators can influence the political sphere (La Nora, 2014, p. 57). Dan Nimmo (1989) in La Nora (2014, p. 59-62) classifies the main communicators in politics as follows: politicians; professional; and activists.

First, Politicians: Politicians as political communicators. Daniel Katz in Nimmo, (1989) cited by (La Nora, 2014) distinguished politicians into two different things: ideological politician (statesman) and participant politician. 1) Ideological politicians are people who fight more for the common good/public in the political process. They are more preoccupied by setting broader policy goals, even supporting revolutionary change, if this brings about good for nations and states. 2) Participant politicians are people who fight more for the interests of a subscriber or group in the political process. Second, Professional: Professionals are people who make a living by communicating, because communication is a skill. A professional communicator, as defined by James Carey 
(Nimmo, 2011, p. 33) is a broker of symbols, a person who translates the attitudes, knowledge, and interests of a language community into the terms of other different language communities, but they are exciting and understandable. Professionals include journalists on one side and promoters on the other. Third, Activist: An activist is a political communicator who acts as an organizational and interpersonal channel. In organizations, there are spokespersons for organized interests.

Relating to the political actors in political communication also requires political leadership, because in political communications run by the leader, they must be able to influence members and audiences with various ideas or policies. Leadership based on ideas usually has an evocative and inspiring power (La Nora, 2014, p. 64).

Leadership is understood in three perspectives: 1) Leadership as a behavior pattern; 2) Leadership as a personal quality; 3) Leadership as a political value. As a behavioral pattern, leadership is related to the ability to influence others in pursuing goals. As a personal quality, leadership is related to charisma. As a political value, leadership is concerned with the ability to move others with moral authority or ideological views (Alfian, 2009, p. 191).

In a message, communication is important between communicator and communicant and will occur if the message is delivered correctly. Messages are anything that someone conveys in the form of symbols perceived and accepted by audiences in a series of meanings (Cangara, 2016, p. 281). ${ }^{3}$ Message communication (a message) has a specific purpose. It determines which techniques to use, whether it is information engineering, persuasion

\footnotetext{
3 The symbol has a function as the bridge in communication, from sounds, signs, and colors to modified symbols in the form of signals through air and light waves, such as television radio, telegram, telex and satellite (Cangara, 2016:281).
}

techniques, or instructional techniques. The contents of a communication message can be singular, but the symbols used can be various. Symbols that can be used to convey the contents of the communication are language, image, color, gesture, and so on (Effendy, 2003, p. 37-38). Cangara (2016, p. 281) explains that, according to the form, the symbols conveyed can be divided into two kinds: verbal symbols and nonverbal symbols. The verbal symbolis used as language. In political practice, the communication system will also be influenced by the existence of the political system. A democratic political system, for example, will provide a democratic communication process (in the communication system) as well (Nurdin, 2005, p. 21).

Achieving a political goal is also determined by a political message. The more powerful and influential the political message,the greater possibility of the public understanding the message being conveyed. Messages in non-verbal forms are more effective than verbal forms, such as in political campaigns held over a period of time through party candidates or political actors. Roger and Storey (1987) in (La Nora, 2014, p. 135) define the campaign as "a set of planned communication actions with the aim of creating a certain effect on a large number of audiences being sustained over a period." Referring to this definition, every activity of a communication campaign must contain at least four things: 1) campaign action aimed at creating a certain effect or effects 2) a large number of target audiences 3) usually concentrated over a period of time 4) through a series of organized communication actions (Venus, 2004, p. 7).

In the election domain, a governor election or presidential political campaign by political parties cannot be separated as part of political communication. The campaign is intended to communicate the political content and messages of political parties or actors themselves. According to Kotler and Roberto 
(1989), in (Cangara, 2016, p. 245), “Campaign is an organized effort conducted by one group (the change angent) which intends to persuade others (the target adopters), to accept, modify, or abandon certains ideas, attitudes, practices, and behaviors." The campaign is an effort organized by a group (agents of change) aimed at persuading their target to receive, modify, or discard certain ideas, attitudes, and behaviors. As a form of message delivery, campaign messages are also open to discussion, and even the underlying ideas behind the campaign are also open to criticism. Such openness is possible because the ideas and objectives of the campaign are essentially good for the public (La Nora, 2014, p. 136). Imawan (1997) in Amir (2006) quoted by (Syah Putra, 2015, p. 56-57) formulated several techniques of political campaigns. They are: First, a door-todoor campaign, the popular term "blusukan". Second, group discussions are conducted by forming small discussion groups. Third, the direct mass campaign; this model is the most classic and the most widely used in the run up to the election. Fourth, the indirect mass campaign, which means where politicians do not meet with their constituents.

The use of various campaign techniques by political candidates or actors means that political messages in the form of political plans and policies proclaimed and executed can be well-accepted by the community. The message from the campaign highlights the idea that the candidate or candidate wants to share with voters. Messages often consist of several points talking about policy issues (La Nora, 2014, p. 139).

Political messages such as language, images, colors, and gestures are often encountered during a politocal campaign. Hafied Cangara (2011: p. 270) adds that messages compiled using these techniques will be effective if delivered with propaganda that blends them. Progaganda can be said to be a very popular form of persuasion in politics. Proganda is taken from the word propagare, which means "to develop" or "to split". In political terms, this means a series of messages that aim to influence the opinion and behavior of the community or a group of people.

The element in politics that now seems to be a political trend is imaging. Viewed from the perspective of political communication, PAN's victory in Ngada is inseparable from the imaging that was built, both political and outside of politics. In some sources, the authors find that the image of the main character (Marianus Sae) in Ngada is very strong in proximity to the naturally characterized society, and this tendency occurs outside of the political and campaign schedule.

Imaging in politics is an important part because the image is a message directly captured by the public. Therefore, political actors will primarily intersect with selfnomination to maintain animage as part of political communication. Anwar Arifin, (2011, p. 193) quotes Jean Baudrillard's idea of the formulation of the imaging phase, at least the stage in building the image through four processions: 1) the representation in which imagery is a reality mirror; 2) the ideology in which images conceal reality, where the image simply rebuilds the reality of the shadow because it assumes that the existing reality is false or unsuitable; 3 ) the image hides that reality is essentially absent, and 4) the image is totally unrelated to even a small part ofreality.

Political communicationcannot be separated from political imagery, which is intended to form the public opinion of the leader or candidate. Opinions are active responses to thestimulant, responses composed through personalized interpretations that are derived and contribute to image formation. Each opinion reflects a complex organization consisting of three components - trust, value and hope (Nimmo, 2010, p. 10). 


\section{Discussion}

\section{PAN Victory as a Symbol of the Decline of Public Belief in the Party}

Civil society is a part of party life; without civil society, political parties cannot stand alone. Perez-Diaz emphasizes the meaning of civil society to the state of a society which has undergone a limited government, freedom, market economy, and the emergence of independent community associations, which are supports for each other (Gaffar, 2006, p. 178). Independence is an important factor in social life. The community cannot be totally dependent on the government. The role of government and state is as a control institution that enables the welfare of society. The state plays a greater role in areas of a political nature, or matters which are the mission of the regime in power. Beyond that, ideas such as creativity and innovation, as well as efforts to survive, are the responsibility of society itself independently.

Therefore, what is the role of the party in disadvantaged areas like most of Eastern Indonesia, such as in the Ngada district? It seems most people will answer there is no role. This was also the case in Ngada when PAN became a party whose electability suddenly peaked. Some of the researcher interviews with community groups, non-govermental organizations, and DPRD members explain the same answer,that PAN's electivity in Ngada is not because people believe in PAN as a political party, but that there are more important things outside the party. Mujani and Liddle (2010) in (Utomo, 2013, p. 77) show that in 2004, the rate of partisanship in Indonesia was in the range of $60 \%$.

This number continues to decline, and in 2009 it became only about $22 \%$. The significant collapse in party identity can be identified as a form of disappointment of the community in the political parties in Indonesia. This view is more synchronous if placed on the national political phenomenon in general and will be abstract if it is paired with political phenomena at the regional level, specifically in Ngada district. The Ngada people have no sense of disappointment in any party, but having a sense of distrust in the party is a certainty.

This is directly proportional to the level of understanding and public views of the political and party existence. If only there were a form of community partisanship that was only seasonal. One of the community leaders in Ngada, Nikolaus Moka, said that " "Kami tidak lihat partainya, tetapi yang kami lihat ialah siapa aktor di dalamnya" ("We do not see the party, but what we see is who the actors are in it") (Interview with Ngada community leaders, April 23, 2017). This shows that there is no particular concern from the public against the party either in terms of political ideology, the party chairman, or the national electability of the party until political turmoil occurs and so forth. It also breaks the view (Haryanto, 2014, p. 331) in his research which explains that the contemporary reality in South Sulawesi has provided an early picture that Indonesian voters have begun to identify themselves with the party in determining their chosen candidate. It has also been affirmed (Utomo, 2013, p. 76), that political figures or candidates become more important than political parties. Ideology and connections are no longer sufficient to explain voting behavior. Meanwhile, (Aminudin, 2016, p. 8) citing (Mair, 1996) explains that the general factors that degrade the party's image in the community have a direct impact on the emergence of negative campaigns against the party. However, this is not the case in Ngada. PAN's victory is actually more influenced by the factors of fame, or the image of the actors

\footnotetext{
$\overline{4 \text { Nikolaus Moka }}$ (Public Figure). This opinion is also similar to some people such as non-govermental organizations and the Chief and the Vice of Regional House of Representatives in Ngada, the success team and the voters that the figure exceeds the great name of party. However, it is not apart from some figures with the opposite views.
} 
who participated, as seen by the community. In addition to the factors of the figures, another factor is the work program that have been run by the Mulus pair during the period of his leadership in the first period. Another important factor, and aconcern to the author, is the emotional closeness built by the political actors themselves, in this case, the Mulus pair.

During the study period, the authors also found several views of society and community leaders who criticized the leadership of the Mulus pair from the first period to the second, related to development and political policy. However, the success in the second period is attributed to the public trust given through the voting rights which elected the Ngada party in power.

There are at least four major factors affecting PAN's electability increase and the PAN victory in the Ngada district elections:

\section{The influence of a figure}

PAN's electability and victory are inseparable from the influence of the politicians or actors involved in it. Some sources say that Marianus Sae and Paulus Soliwoa's duties are very close to the community. This is different from the previous leaders of Ngada, who may be said to have an exclusive attitude that creates far-reaching space and distance between leaders and society. The fame of Marianus and Paul is so simple and populist that it becomes a positive judgment for society and increases the pair's political value in their party.

For the public, the figure is considered a representation of ideas, and political parties are no longer an important institution to channel political choice. In other words, public attention is drawn to the attention of "who", not "what" and "how" political platforms are promoted by candidates and political parties (Utomo, 2013, p. 76).

Meanwhile, a member of Parliament Ngada said that the figure and the duties of Marianus are humanist and repressive, according to his view that Marianus is not pro- gender or for those in poverty, the elderly, those blind and those widowed. According to him, it becomes important to be considered by other physical development factors, such as roads, lighting, and water for the Ngada community.

\section{Work Programs}

Work programs run by the Mulus pair, both from the first to second period, included the areas of economy, education, health, and infrastructure. The economic field, through silver programs, includes: Silver Livestock, Forestry Silver, Agricultural Silver, and Silver Horticulture. In the health sector, among others, there is JKMN (Jaminan Kesehatan Masyarakat Ngada/ Public Health Insurance of Ngada), procurement paramedical staff and medical scholarships for as many as 30 people, established in cooperation with Sangrila Hospital. Education areas include Bantuan Dana Operasional Daerah (Bosda), Bantuan Operasional Pendidikan (Bosdik), and scholarships for children who cannot afford it. Infrastructure areas include $1041 \mathrm{~km}$ of road construction since 2010; this road also opens up isolated places so it is easy for the community to access the road, as an improvement of the society's economy.

The programs above are the work programs that have been the focus of the Mulus pair since the first period, in addition to other work programs that support development in Ngada district. Work programs in this first period, for most people Ngada, greatly touch the needs of the community, and it is seen by the public that the Mulus pair answers the needs of the community, so the work of the pair needs to be resumed in the second period. Both the political actors and the winning team of the Mulus pair explained that, in the first period, the pair had been trusted by the most people, so in the second period, the campaign issues added were road construction, distribution or evenness of lighting (electricity), and water supply for the community. Based on the 
principles that the Mulus pair has undertaken in political and developmental work that has been perceived and seen by the public, they only need to continue the work programs in the second period.

\section{Emotional Approach and Closeness}

Basically, Ngada society in everyday life is inseparable from social and cultural life. In particular, things related to culture are mandatory and must be undertaken by Ngada society as an integral part of everyday life. The Ngada community is a social society with a great level of social awareness. Gotong royong is a feature of life in Ngada society. Marianus Sae and Paul Soliwoa are an inseparable part of social and cultural activities within society. In various activities, Marianus and Paul always take part in the community, mingling with the community and working with them. This can be seen from the involvement of the political actors in the activities of death, weddings or traditional feasts that are often done by the Ngada community. With the involvement of political actors in various socio-cultural activities, the public builds opinions and draws the conclusion that political actors (Marianus and Paul) are simple political actors, mingling and close to society.

La Nora (2014, p. 179) describes several factors of voter behavior, which are seen from sociological models, psychological models and rational models. The Sociological Model is based on the idea that voter behavior in political responses is based on socioeconomic status and socioreligious affiliation. This model relates itself to the ethnic, racial, religious, family, and emotional ties that voters historically experience, because they have a major role in shaping one's attitude, perception, and orientation. The Psychological Model explains that the attitude of voters is a reflection of the personality of a person, which becomes a decisive variable in influencing voter political behavior. This model prioritizes the three psychological pillars, namely the emotional bonding of political parties, the orientation of the issue, and the orientation of the candidate. The Rational Model, however, sees the behavior of voters as a product of profit and loss calculations.

Thus, PAN's victory is influenced by the social and psychological approaches of the elites to society, which influence voter behavior in Ngada. Being between the political context and the cultural context, the elite play two roles at once, namely as political elite and as a traditional society (culture). By playing the role of the elite in the traditional sphere, the public sees the elite as part of society (Sociology and Psychology Model), while, in different contexts, the community views the elite as a political actor in policy making (Rational Model). Therefore, what society sees is a political elite that acts as acommunityon one side, and as apolitician on the other side. In the political context in Ngada, PAN's power comes from the images of the political actors, because of the lack of public confidence in the party. Political parties are only a bridge to capture the masses. These symptoms may be referred to as 'deparpolization' symptoms. The phenomenon of 'deparpolization' affirms a phenomenon called political personalitation. Political figures or candidates become more important than political parties. Ideology and committments are no longer sufficient to explain voting behavior (Utomo, 2013, p. 76).

\section{Conclusion}

In the political context of Ngada, especially in relation to PAN's power in Ngada, people won the party not because of the party's ideology, or the size of the party, but because of the political actors within the party. The mistrust of the community against the party occurs because the community has alimited understanding of the political party. The failure of political communication of this party makes the level of public confidence decrease. For example, PAN's victory in Ngada is not a success of PAN in building political 
communication, but instead is due to the ability of local political actors to build political communication in Ngada. The influence of Marianus Sae on PAN's increased electability in Ngada increased drastically in the legislative elections of 2014. PAN's victory is a picture of Ngada's public distrust of political parties, of PAN and also the other large parties in Ngada. By building the right political communication in the political and socio-cultural realm, political actors won for PAN. Political actors in PAN play two roles at the same time in building the trust of Ngada society, with the party as a bridge: the role of the political elite, as a politician in policy making, and as part of Ngada society with the involvement of actors in the socio-cultural affairs of Ngada. With the actors in these two roles, it affects the level of public confidence in the actors, while the level of trust in the party has nothing to do with PAN's victory at the political context level in Ngada. This is due to the failure of political communications built by the party, so that PAN's victory is a form of public trust to actors as well as a form of public distrust of the party.

\section{References}

Ada Skenario Gagalkan Pilkada Ngada, Mendagri: Ya Dituda 2017. (n.d.). Retrieved October 14, 2016, from http://m.sergapntt. $\mathrm{com} / \mathrm{s}$

Alfian, M. A. (2009). Menjadi pemimpin politik: perbincangan kepemimpinan dan kekuasaan. Jakarta: Gramedia Pustaka Utama.

Ali, N. (1999). Peradapan komunikasi politik: potret manusa Indonesia. Bandung: Remaja Rosdakarya.

Aminudin, M. F. (2016). Electoral system and party dimension assestment in democratic Indonesia. Jurnal Ilmu Sosial dan Ilmu Politik, 20(1), 1-15. doi: 10.22146/jsp.17956

Arianto, B. (2016). Menakar peran relawan politik pasca kontestasi presidensial 2014. Jurnal Ilmu Sosial dan Ilmu Politik, 20(1), 5068. doi: $10.22146 /$ jsp. 18000
Arifin, A. (2011). Komunikasi politik: filsafatparadigma-teori-tujuan-strategi dan komunikasi politik Indonesia. Yogyakarta: Graha Ilmu.

Asrinaldi. (2014). Kekuatan-kekuatan politik di Indonesia. Yogyakarta: Tiara Wacana.

Bungin, B. (2008). Penelitian kualitatif: komunikasi, ekonomi, kebijakan publik, dan ilmu sosial lainnya. Jakarta: Kencana Prenada Media Group.

Cangara, H. (2009). Komunikasi politik: konsep, teori dan strategi. Jakarta: Rajawali Pers.

Cangara, H. (2011). Komunikasi politik: konsep, teori dan strategi (2011 ed.). Jakarta: Rajawali Pers.

Cangara, H. (2016). Komunikasi politik: konsep teori dan strategi (2016 ed.). Jakarta: Rajawali Pers.

Effendy, O. U. (2003). Ilmu Komunikasi teori dan praktek. Bandung: PT Remaja Rosdakarya.

Fadillah, D. (2014). Strategi Komunikasi peningkatan partisipasi politik kader perempuan Partai Amanat Nasional (PAN) Kabupaten Sleman dalam pemilu legislatif 2014 (Unpublished master's thesis). Universitas Gadjah Mada Yogyakarta.

Gaffar, A. (2006). Politik Indonesia transisi menuju demokrasi. Yogyakarta: Pustaka Pelajar.

Haris, S. (2014). Partai, pemilu dan parlemen era reformasi. Jakarta: Yayasan Pustaka Obor Indonesia.

Haryanto, H. (2014). Kebangkitan Party ID: Analisis perilaku memilih dalam politik lokal Indonesia. Jurnal Ilmu Sosial dan Ilmu Politik, 17(3), 291-308. doi:10.22146/jsp.13082

Holik, I. (2005). Komunikasi politik dan demokratisasi di Indonesia: dari konsolidasi menuju pematangan. Jurnal Madani II, November, 56-74. Retrieved from http:// download.portalgaruda.org/article. php? article $=19483 \&$ val $=1231$

Huntington, S. P., \& Nelson, J. (1994). Partisipasi politik di negara berkembang (S. Simamora, Trans.). Jakarta: Rineka Cipta. 
Ini Nama Calon Anggota DPRD Ngada Terpilih. (n.d.). Retrieved October 4, 2016, from http://www.tribunnews.com

La Nora, G. A. (2014). Ilmu komunikasi politik. Yogyakarta: Andy.

Marshment, J. (2009). Political marketing. Oxon: Routledge.

Nimmo, D. (2010). Komunikasi politik khalayak dan efek. Bandung: PT Remaja Rosdakarya.

Nimmo, D. (2011). Komunikasi politik: komunikator pesan dan media. Bandung: PT Remaja Rosdakarya.

Nurdin. (2005). Sistem komunikasi Indonesia. Jakarta: Rajawali Pers.

Nurhadi, Z. F. (2015). Teori-teori komunikasi. Bogor: Ghalia Indonesia.

Syah Putra, D. K. (2015). Komunikasi CSR politik. Jakarta: Prenadamedia.
Utomo, W. P. (2013). Menimbang media sosial dalam marketing politik di Indonesia: belajar dari Jokowi-Ahok di Pilkada DKI Jakarta 2012. Jurnal Ilmu Sosial dan Ilmu Politik, 17(1), 67-84. doi: 10.22146/jsp.10894

Venus, A., S., R. K., \& Rakhmat, J. (2004). Manajemen kampanye: panduan teoritis dan praktis dalam mengefektifkan kampanye komunikasi. Bandung: Simbiosa Rekatama Media.

Wahidin, S. (2008). Mengawasi pemilihan umum kepala daerah. Yogyakarta: Pustaka Pelajar.

Yuliyanto, M. (2014). Dinamika komunikasi politik dan pembangunan di era demokrasi. Jakarta: Rajawali Pers.

Yumitro, G. (2013). Partai Islam dalam dinamika demokrasi di Indonesia. Jurnal Ilmu Sosial dan Ilmu Politik, 17(1), 35-50. doi: 10.22146/ jsp.10892 